\title{
Behaviour of pre-parturient sows housed in intensive outdoor or indoor systems
}

\author{
Maria José Hötzel(1), Luiz Carlos Pinheiro Machado Filho(1) and Osmar Antônio Dalla Costa(2)
}

\begin{abstract}
(1)Universidade Federal de Santa Catarina, Dep. de Zootecnia e Desenvolvimento Rural, Rod. Admar Gonzaga, 1346, Itacorubi, CEP 88034-001 Florianópolis, SC, Brazil. E-mail: mjhotzel@cca.ufsc.br, pinheiro@cca.ufsc.br (2)Embrapa Suínos e Aves, BR 153, Km 110, CEP 88700-000 Concórdia, SC, Brazil. E-mail: osmar@cnpsa.embrapa.br.
\end{abstract}

\begin{abstract}
This work compared the behaviour of pre-parturient sows housed in intensive confined and outdoor systems, during the morning and afternoon prior to delivery. Eight sows were kept individually in farrowing crates or in paddocks with access to fresh pasture from 8 to 10 days before expected parturition. All outdoor sows built a nest within 24 hours before farrowing. On the morning and afternoon before farrowing they spent $6.5 \%$ of the time collecting grass and $7.5 \%$ of the time organizing the nest. Outdoor sows were observed more often than confined sows rooting $(4.60 \%$ vs. $0.25 \%)$, feeding $(10.2 \%$ vs. $3.0 \%)$, standing (51\% vs. $13 \%)$ and walking ( $8 \%$ vs. $0 \%)$. Indoor sows redirected the nesting behaviour to other behaviours like attempts to dig the ground, nosing, biting and rooting parts of the crate, feeder or drinker, during $4.7 \%$ of the time. They also spent more time than outdoor sows inactive ( $85 \%$ vs. $60 \%)$, lying ( $72 \%$ vs. $41 \%)$, drinking $(2.1 \%$ vs. $0.5 \%)$ and vacuum chewing ( $3.7 \%$ vs. $0.1 \%)$. The pre-parturient behaviour of sows was considerably affected by the husbandry system. The outdoor system appears to be more appropriate for the sows' welfare than the conventional confinement.
\end{abstract}

Index terms: farrowing, welfare, housing, husbandry system.

\section{Comportamento de porcas pré-parturientes alojadas no sistema intensivo ao ar livre ou no confinamento convencional}

\begin{abstract}
Resumo - Neste trabalho foi comparado o comportamento de porcas pré-parturientes criadas no sistema confinado convencional ou no sistema intensivo ao ar livre. Oito porcas foram mantidas individualmente em baias de maternidade ou em potreiros com acesso a pasto fresco, de oito a dez dias antes da data prevista para o parto. As porcas ao ar livre construíram um ninho nas 24 horas antes do parto. Na manhã e tarde antes do parto, passaram aproximadamente $6,5 \%$ do tempo coletando pasto e 7,5\% do tempo organizando um ninho. As porcas ao ar livre foram observadas mais freqüentemente do que as confinadas fuçando (4,60\% vs. 0,25\%), comendo (10,2\% vs. $3,0 \%)$, em pé ( $51 \%$ vs. $13 \%)$ e caminhando ( $8 \%$ vs. $0 \%)$. As porcas confinadas redirecionaram o comportamento de ninho para comportamentos como tentativas de escavar no piso, morder e fuçar partes da baia, o comedouro e o bebedouro, durante $4,7 \%$ das observações. Também foram observadas mais freqüentemente do que as porcas ao ar livre inativas ( $85 \%$ vs. $60 \%)$, deitadas ( $72 \%$ vs. $41 \%)$, bebendo (2,1\% vs. $0,5 \%)$ e mascando em falso $(3,7 \%$ vs. $0,1 \%)$. O comportamento de porcas pré-parturientes foi consideravelmente influenciado pelo sistema de criação. O sistema intensivo ao ar livre parece ser mais apropriado para o bem-estar de porcas nesta fase do que o confinamento convencional.
\end{abstract}

Termos para indexação: pré-parto, bem-estar, alojamento, sistema de criação.

\section{Introduction}

In recent years confinement rearing has become the norm for poultry and swine in industrialized countries, and the system is rapidly spreading to all regions of the globe. Because of the limited space and materials that are available in the confined environment, pigs are unable to perform a series of behaviours of their natural repertoire. Welfare issues related to confinement have attracted public's attention in recent decades; lately these concerns have been linked to the potentially negative impacts of intensive industrial agriculture on human health, society and the environment (Fraser, 2001). Welfare appears to be particularly affected during the pre-parturient period in sows housed in confinement (Barnett et al., 2001; Jarvis et al., 2001).

In extensive and semi-natural environments preparturient sows build a nest during the 24 hours before farrowing (Jensen 1989; Stolba \& Wood-Gush 1989; Jensen et al., 1993). Jensen (1993) suggested that the 
onset of nesting motivation is under endocrine control, but the course of its building would be dependent on the availability of material and other factors of the environment relevant to nest building. In the conventional confined system, sows are transferred to farrowing crates a few days before the expected date of delivery, where they have no access to nesting material or space for locomotion. Depriving sows of space and material to perform the nesting behaviour has been associated with several negative consequences for the welfare of sows and piglets, including abnormal behaviour and physiological stress (Jarvis et al., 2001, 2002), reduced piglet survival (Thodberg et al., 1999) and savaging of piglets (Ahlstrom et al., 2002). Providing confined sows with nesting material or more space during the prefarrowing period can relieve some of these effects (Lawrence et al., 1994; Jarvis et al., 2002), but does not eliminate them completely.

Studies investigating the effects of housing on preparturient sow's behaviour, physiology and welfare have compared responses of animals housed in confinement with different levels of environmental complexity or draw comparisons with results from studies describing the behaviour of animals kept in extensive, semi-natural or wild habitats (Jensen 1989; Stolba \& Wood-Gush 1989; Jensen et al., 1993). The behaviour of pre-parturient sows housed in intensive outdoor systems could add a new insight to the discussion because, unlike extensive systems, the outdoor system has the same productivity goals and applies management methods similar or identical to those used in the confined system, like control of reproduction, nutrition, health and weaning age. The two most relevant elements to the expression of behaviour of pre-parturient sows confined in farrowing crates, i.e. nesting material and space (Lawrence et al., 1994; Cronin et al., 1998; Jarvis et al., 2001), are freely available in the outdoor system. Thus, pre-farrowing behaviour of sows may be significantly different in these two husbandry systems.

The objective of this study was to compare the preparturient behaviour of sows housed in intensive confined or outdoors husbandry systems, during the last morning and afternoon prior to delivery.

\section{Material and Methods}

This study was endorsed by the Ethics Committee on Animal Experimentation of the Universidade Federal de Santa Catarina, according to the recommendations of the Brazilian Association for Animal Experimentation (Colégio Brasileiro em Experimentação Animal).

The experiment was carried out at the experimental research station of Embrapa Suínos e Aves, Concórdia, Santa Catarina State, Brazil, between December 2000 and April 2001, summer/autumn in the region. Mean temperatures at observation times ranged from $22^{\circ} \mathrm{C}$ to $27.8^{\circ} \mathrm{C}$ and did not differ between the systems by more than $2.5^{\circ} \mathrm{C}$. Eight sows housed in each system were used in the experiment. These sows were kept in the same system throughout their whole reproductive lives. They were between their fourth and eighth reproductive cycle when they were used in the experiment.

Sows in indoors environment were kept individually in farrowing crates $(0.75 \times 2.4 \mathrm{~m})$ from $8-10$ days before expected parturition. Temperature in the rooms, which had natural ventilation through wide-open windows, ranged from $15^{\circ} \mathrm{C}$ to $30^{\circ} \mathrm{C}$. The crates had concrete floors, without any bedding. Feed was offered in a trough located in front of the crate. Ad libitum access to water was offered in a nipple drinker positioned in front of the crate.

Sows in the outdoors environment were kept individually in approximately $700 \mathrm{~m}^{2}$ paddocks, from 8-10 days before expected parturition. Paddocks were divided by electric fences, which prevented sows to move to other paddocks. Each sow had access to artificial shade, located close to a rectangular hut made of wood and metal roofing, located in a central site of the paddock. Sows had access to fresh pasture, which they used for nesting material and feed. The pasture, dominated by African star grass (Cynodon plectostachyus), was plentiful during the experiment in all paddocks.

Behaviour was recorded by two trained observers, using instantaneous scan sampling (Lehner, 1996) by direct visual observation from $8 \mathrm{~h} 30$ to $11 \mathrm{~h} 30$ and from $14 \mathrm{~h} 30$ to $18 \mathrm{~h} 30$. The observation of the sows started three days before the expected farrowing day. Only the two last observation periods (morning and afternoon) immediately before delivery were used in the analysis, and these are referred as "last morning + afternoon" throughout the text. Behaviour of each sow was recorded in six scans made at 20 -second intervals, every 15 minutes.

The posture of the sows was first divided in three mutually exclusive categories: lying, lateral or sternal recumbency; sitting, supported only by front legs, in a dog-like position; and standing, supported by four legs, including walking. Additionally, a series of mutually 
exclusive behaviours that could be performed in one of these postures were recorded: walking, animal moving between points in space, either walking or running; feeding, head of animal is over or within feeder, or animal is chewing with food in mouth; grazing, mouth-jaws movement in contact with grass or grazing; drinking, mouth contact with drinker; exploratory behaviours, animal is engaged in searching-like activities, which involve increased overall alertness, sensory focusing, making nasal contact with parts or objects of the pen or paddock and locomotion accompanied by investigation; collecting grass/braches, plucking/transporting grass or branches in mouth to nest site; organizing nest, arranging grass/ branches in a nest-shaped format, inside or outside hut; digging, excavating ground; pawing, attempt to excavate on concrete floor; rooting, snout in contact with ground/ floor/object; pen-directed nosing, nosing/chewing parts of the pen; vacuum chewing, repetitive mouth movement without contact with any substrate; and inactive, not performing any of the above-mentioned behaviours. It was also recorded whether outdoor sows were inside or outside the hut.

Behaviours were expressed as frequency of occurrence over a total of 168 observations/day. The experimental units were the sows ( $\mathrm{n}=8 /$ treatment).

Effects of breeding system (d.f.=1) on frequency of every behaviour were analysed by one-way analysis of variance (Snedecor \& Cochran, 1989) using the SuperANOVA package (Abacus Concepts, Inc., USA). Logarithmic transformation of the data to correct heterogeneity of variance did not alter results of the analysis. Data are shown untransformed. Behaviours that were very rare or absent in one of the treatments were analysed by non-parametric statistics (MannWhitney U). Data are presented throughout the results section as means \pm standard error.

\section{Results and Discussion}

Sows housed outdoors in this study appeared to carry out the complete nest-building repertoire described in sows kept in extensive and semi-natural environments (Jensen, 1986; Jensen et al., 1993). All of them presented all the phases described by Jensen (1986): nest-site seeking, nest-building and farrowing. They spent a great deal of their time during the last morning + afternoon before delivery in activities like gathering straw and fresh pasture $(6.4 \pm 3.0 \%$, range $0.6 \%$ to $17.9 \%)$ and organizing a nest $(7.6 \pm 2.2 \%$, range from $2.3 \%$ to $13.7 \%)$.
Other activities related to nesting observed in these sows were walking, digging soil, rooting and exploring (Figure 1). Sows take 5 to 10 hours to build the nest (Jensen, 1993), with considerable variation among individual sows in the total amount of time spent on nesting behaviour during the 24 hours before delivery (Jensen et al., 1993). This possibly explains the variation observed among animals in the amount of time spent displaying each of the behaviour related to nesting. All the sows in the outdoor environment built a nest into which they delivered their piglets, reinforcing that the motivation to perform this behaviour is highly conserved in domestic sows (Gustafsson et al., 1999), and that domestic sows build a nest whenever the environmental conditions allow them (Jensen, 1993; Damm et al., 2000).

Some nests were built inside the huts provided in the paddocks, while others were built anywhere in the field. Outdoor sows spent $19.1 \pm 8.0 \%$ of the time inside the hut. Jensen (1989) found that sows tended to build the nest under shelter or in a more protected site during winter but anywhere in the field away from their home range and as much as possible isolated from the rest of the herd during summer. He suggested that the function of this behaviour would be to isolate the litter from the herd, which would be beneficial for the bonding between mother and young and decrease the possibility of intersucking among litters. Although the sows in the present study were isolated from each other by electric fences, the choice of nest site might be related to the need to isolate themselves from the other sows, because the size

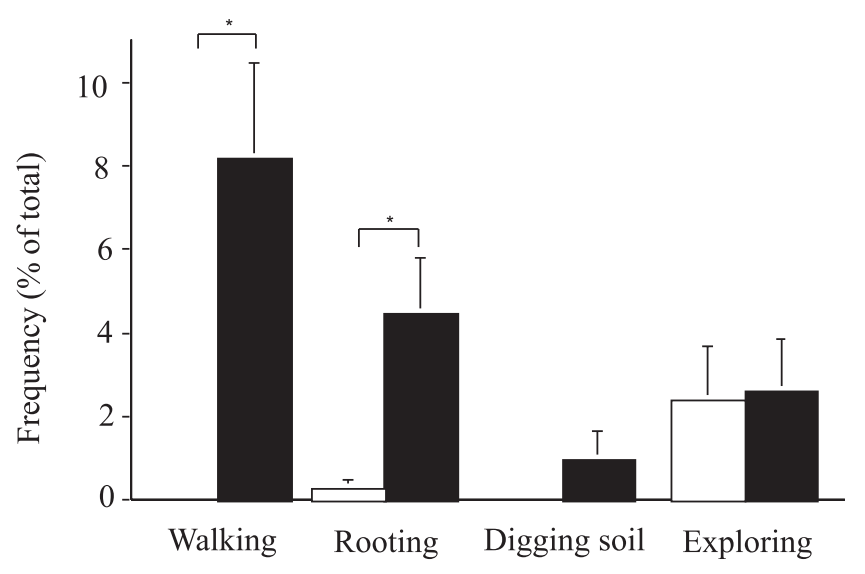

Figure 1. Frequency of walking, rooting, digging soil and exploring behaviours in sows housed in the confined $(\square)$ and outdoor (ם) system, during the 24 hours prior to delivery. Values are means \pm standard error $(\mathrm{n}=8)$. $* \mathrm{P}<0.01$. 
of the paddocks forced a considerable degree of proximity among sows. The nests were made of fresh pasture collected by the sows from the paddock. Several authors report a tendency of sows to use branches to build the nest when the material is available (Jensen 1986, 1989), but these were not present in the paddocks in which the sows were installed. A high variation among individual animals in the amount of material used to build the nest was reported (Jensen, 1986), which was also observed in this study.

This study supports others reporting that domestic sows try to build a nest even in the absence of suitable space or material (Jensen, 1993; Jarvis et al., 2001, 2002). As shown in other studies, in the absence of appropriate material, sow behaviour was directed at pen fixtures (Lawrence et al., 1994; Jarvis et al., 2001, 2002). As opposed to nesting behaviour performed by outdoor sows, confined sows, which did not have access to material to build a nest, spent part of the last hours prior to delivery displaying behaviours such as pawing, rooting, nosing and biting parts of the crate. These behaviours were present in all the experimental sows kept in the crates and represented collectively $4.7 \pm 1.6 \%$ of the behaviours. Biting and chewing pen equipment was related by Jensen (1993) to vacuum-like gathering of material or behaviour derived from the typical motor pattern for tearing twigs and branches from trees and bushes.

Although behaviours associated with motivation to build a nest occurred in the confined sows, these occupied less than half the time spent on the normal nesting behaviour by outdoor sows during the hours before delivery. This may be related to the lack of material and other factors of the environment that, according to Jensen (1993), are thought to influence the second phase of nest building. Confined gilts deprived of any nesting material perform less pawing and rooting than gilts with access to straw (Thodberg et al., 1999; Burne et al., 2000). Some studies report an increase in frequency and length of nesting activity in confined sows when substrates such as straw or sawdust are available during the pre-parturient phase, as opposed to when farrowing in barren pens (Thodberg et al., 1999).

Compared to outdoor sows, confined sows spent less time standing and a greater proportion of time inactive and lying (Figure 2). In contrast, outdoor sows spent from $2.5 \%$ to $21 \%$ of the time walking (Figure 1). Domestic sows kept in large areas perform large amounts of locomotion during the pre-parturient phase (Jensen,
1986; Stolba \& Wood-Gush, 1989). Jensen (1986) reported that sows walk up to $6.5 \mathrm{~km}$ during the prefarrowing phase, searching for a farrowing site. Under confinement, the provision of space increases activity and the time pre-parturient sows spend standing and walking (Cronin et al., 1998; Jarvis et al., 2002). On the other hand, lack of space restricts the use of straw (Jarvis et al., 2002), suggesting that activity and locomotion are important for the full expression of normal behaviour of pre-parturient sows. Exercise, an important component of the pre-parturient behaviour that could be expressed in sows raised outdoors but not in sows in the confined system, may have consequences beyond sow welfare like, for example, piglet survival at parturition (Barnett et al., 2001). Piglet survival from these experimental animals was reported elsewhere (Hötzel et al., 2004) and did not differ between the two treatments, although the number of replicates was too small in this experiment to investigate this kind of variable.

Confined sows, compared with outdoor sows, spent a higher proportion of time drinking $(2.1 \%$ vs. $0.5 \%$; $\mathrm{p}<0.05)$ and vacuum chewing (3.7\% vs. $0.1 \%$; $\mathrm{p}<0.01)$. Stereotyped, excessive drinking, and vacuum chewing have been associated with feeding motivation or hunger (Rushen, 1984; Terlouw et al., 1991) and with boredom (De Jong et al., 1998). Ad libitum feeding (Bergeron et al., 2000), increasing the energy of the diet (Bergeron \& Gonyou 1997) or feeding bulky high-fibre regimens (Robert et al., 1993) to confined sows, reduce these stereotypies in sows. Although feed consumption was not measured, there was a considerable difference between treatments in time spent on feeding $(\mathrm{p}<0.01$;
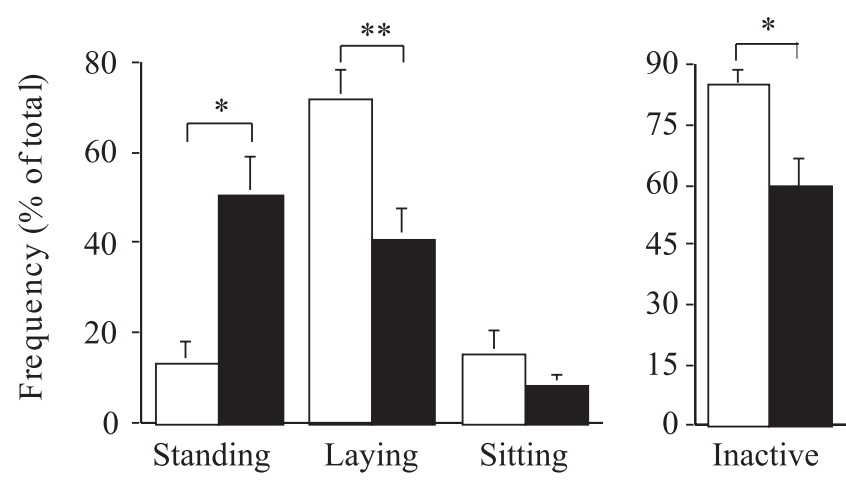

Figure 2. Frequency of standing, lying or sitting and time spent inactive by sows housed in the confined ( $\square$ ) and outdoor $(\square)$ system, during the 24 hours prior to delivery. Values are means \pm standard error $(\mathrm{n}=8)$. $* \mathrm{P}<0.01$. $* * \mathrm{P}<0.001$. 
Figure 3). This was related mostly to the permanent access to pasture in the outdoor system, which allowed the sows in the outdoor treatment to eat the same ration over a longer period. Even if the nutritional value of the pasture for the diet was considered low, it may have been important in fulfilling the motivation to forage caused by lack of satiation, following solid food, normally observed in confined sows (Rushen, 1984). Thus, the effects of husbandry system on feeding behaviour might explain the differences in these abnormal behaviours observed. Drinking and vacuum chewing did not differ between the systems in the same sows, kept in the same system during the lactation period (Hötzel et al., 2004), suggesting that these behaviours may also be related to the frustration caused by being unable to fulfil the nestbuilding motivation. The frequency of other behaviours considered abnormal for the species (following the definition of Fraser \& Broom, 1990) was very low in all the sows, with rare cases of sows observed salivating or head-tilting in the confined environment. Sitting, which is also considered abnormal for pigs, did not differ significantly between treatments (Figure 2).

As proposed by Fraser et al. (1997), one of the three major concerns of the public, which drive scientists to study animal welfare, is that animals should lead natural lives through their development and should be able to use their natural adaptations and capabilities. Dawkins (2004) proposed that one of the two central questions for the study of animal welfare is whether animals have what they want. Nesting behaviour is clearly one example of a natural adaptation of the species, as well as a behaviour that sows are highly motivate to perform,

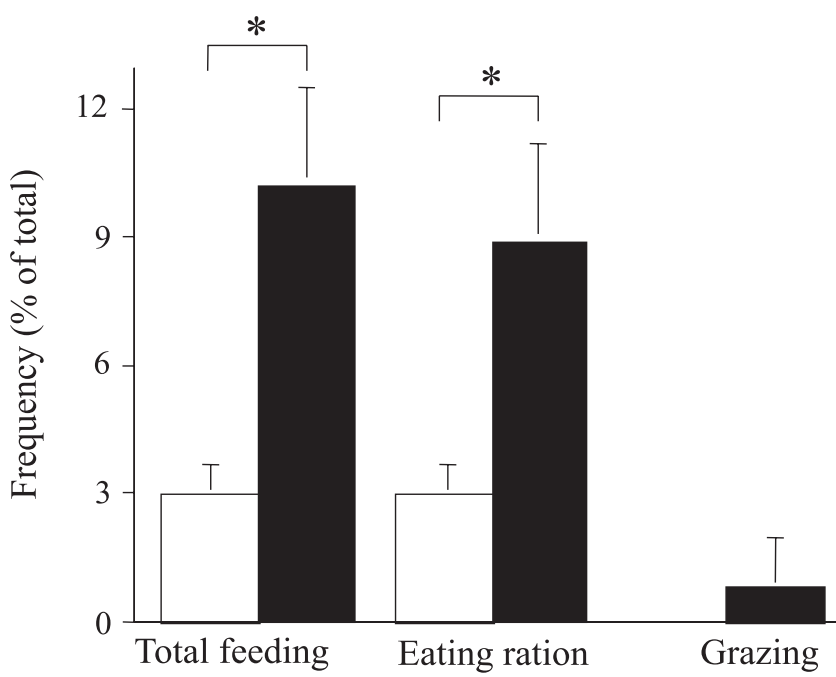

Figure 3. Frequency of feeding behaviour in sows housed in the confined $(\square)$ and outdoor $(\square)$ system, during the 24 hours prior to delivery. Values are means \pm standard error $(n=8)$. $* \mathrm{P}<0.01$. judging from the present observations of confined and outdoor sows. Lawrence et al. (1994) concluded that the differences in behaviour observed in sows housed in crates or in pens with straw may indicate that the substrate-directed behaviour observed in the crated animals is not the motivational equivalent of the apparent nest-building observed in pens. Additionally, studies that have focused on stress physiology during the prefarrowing period indicate that crates may be a source of physiological stress for sows (Lawrence et al., 1994). Lack of space and nesting substrate have been shown to increase the activity of the hipothalamus-pituitaryadrenal axis in pre-farrowing sows confined in crates (Jarvis et al., 2002). Added together, these findings suggest that during the pre-farrowing period the welfare of confined sows is poorer than that of outdoor sows.

\section{Conclusions}

1. Sows in the outdoor system build a nest where they deliver the litter, whereas confined sows redirect the motivation to fulfil the nesting behaviour to objects of the pen.

2. Abnormal behaviours like those related to the redirected nesting behaviour, vacuum chewing and excessive drinking are only present in the confined system.

3. Altogether, this study shows that the pre-parturient behaviour of sows is considerably affected by the husbandry system.

\section{Acknowledgements}

To the Universidade Federal de Santa Catarina (Funpesquisa) and Embrapa, for the research grant; to the Conselho Nacional de Desenvolvimento Científico e Tecnológico (CNPq), for awarding a visiting Researcher fellowship to the first author.

\section{References}

AHLSTROM, S.; JARVIS, S.; LAWRENCE, A.B. Savaging gilts are more restless and more responsive to piglets during the expulsive phase of parturition. Applied Animal Behaviour Science, v.76, p.83-91, 2002.

BARNETT, J.; HEMSWORTH, P.; CRONIN, G.; JONGMAN, E.; HUTSON, G. A review of the welfare issues for sows and piglets in relation to housing. Australian Journal of Agricultural Research, v.52, p.1-28, 2001.

BERGERON, R.; GONYOU, H.W. Effects of increasing energy intake and foraging behaviours on the development of stereotypies 
in pregnant sows. Applied Animal Behaviour Science, v.53, p.259270, 1997.

BERGERON, R.; BOLDUC, J.; RAMONET, Y.; MEUNIERSALAUN, M.C.; ROBERT, S. Feeding motivation and stereotypies in pregnant sows fed increasing levels of fibre and/or food. Applied Animal Behaviour Science, v.70, p.27-40, 2000.

BURNE, T.H.J.; MURFITT, P.J.E.; GILBERT, C.L. Deprivation of straw bedding alters PGF(2alpha)-induced nesting behaviour in female pigs. Applied Animal Behaviour Science, v.69, p.215-225, 2000.

CRONIN, G.M.; DUNSMORE, B.; LEESON, E. The effects of farrowing nest size and width on sow and piglet behaviour and piglet survival. Applied Animal Behaviour Science, v.60, p.331-345, 1998.

DAMM, B.I.; VESTERGAARD, K.S.; SCHRODER-PETERSEN, D.L.; LADEWIG, J. The effects of branches on prepartum nest building in gilts with access to straw. Applied Animal Behaviour Science, v.69, p.113-124, 2000.

DAWKINS, M.S. Using behaviour to assess animal welfare. Animal Welfare, v.113, p.S3-7, 2004.

DE JONG, I.C.; EKKEL, E.D.; VAN DE BURGWAL, J.A.; LAMBOOIJ, E.; KORTE, S.M.; RUIS, M.A.W.; KOOLHAAS, J.M.; BLOKHUIS, H.J. Effects of strawbedding on physiological responses to stressors and behavior in growing pigs. Physiology $\&$ Behavior, v.64, p.303-310, 1998.

FRASER, A.F.; BROOM, D.M. Farm Animal Behaviour and Welfare. 3.ed. London, UK: Baillière Trindall, 1990. 437p.

FRASER, D.; WEARY, D.M.; PAJOR, E.A.; MILLIGAN, B.N. A scientific conception of animal welfare that reflects ethical concerns. Animal Welfare, v.6, p.187-205, 1997.

FRASER, D.; MENCH, J.; MILLMAN, S. Farm Animals and Their Welfare in 2000. In: SALEM, D.J.;. ROWAN, A.N. (Ed.). State of the Animals 2001, Gaithersburg, MD: Humane Society Press, 2001, p.87-99.

GUSTAFSSON, M.; JENSEN, P.; DE JONGE, F.H.; ILLMANN, G.; SPINKA, M. Maternal behaviour of domestic sows and crosses between domestic sows and wild boar. Applied Animal Behaviour Science, v.65, p.29-42, 1999.

HÖTZEL, M.J.; PINHEIRO MACHADO, F.L.C.; WOLF, F.M.; DALLA COSTA, O.A. Behaviour of sows and piglets reared in intensive outdoor or indoor systems. Applied Animal Behaviour Science, v.86, p.27-39, 2004.

JARVIS, S.; VAN DER VEGT, B.J.; LAWRENCE, A.B.; MCLEAN, K.A.; DEANS, L.A.; CHIRNSIDE, J.; CALVERT, S.K. The effect of parity and environmental restriction on behavioural and physi- ological responses of pre-parturient pigs. Applied Animal Behaviour Science, v.71, p.203-216, 2001.

JARVIS, S.; CALVERT, S.K.; STEVENSON, J.; VANLEEUWEN, N.; LAWRENCE, A.B. Pituitary-adrenal activation in pre-parturient pigs (Sus scrofa) is associated with behavioural restriction due to lack of space rather than nesting substrate. Animal Welfare, v.11, p.371-384, 2002.

JENSEN, P. Observations on the maternal behaviour of free-ranging domestic pigs. Applied Animal Behaviour Science, v.16, p.131142, 1986.

JENSEN, P. Nest site choice and nest building of free-ranging domestic pigs due to farrow. Applied Animal Behaviour Science, v.22, p.13-21, 1989.

JENSEN, P. Nest building in domestic sows: the role of external stimuli. Animal Behavior, v.45, p.351-358, 1993.

JENSEN, P.; VESTERGAARD, K.; ALGERS, B. Nestbuilding in free-ranging domestic sows. Applied Animal Behaviour Science, v.38, p.245-255, 1993.

LAWRENCE, A.B.; PETHERICK, J.C.; MCLEAN, K.; DEANS, L.; CHIRNSIDE, J.; VAUGHAN, A.; CLUTTON, E.; TERLOUW, E.M.C. The effect of environment on behaviour, plasma cortisol and prolactin in parturient sows. Applied Animal Behaviour Science, v.39, p.313-330, 1994.

LEHNER, P.N. Handbook of Ethological Methods. 2.ed. Cambridge, UK: Cambridge University Press, 1996. 403p.

ROBERT, S.; MATTE, J.; FARMER, C.; GIRARD, C.; MARTINEAU, G. High-fiber diets for sows - effects on stereotypies and adjunctive drinking. Applied Animal Behaviour Science, v.37, p.297-309, 1993.

RUSHEN, J. Stereotyped behaviour, adjunctive drinking and the feeding periods of tethered sows. Animal Behaviour, v.32, p.10591067, 1984.

SNEDECOR, G.; COCHRAN, W. Statistical Methods. 8.ed. Iowa: Iowa State University Press, 1989.

STOLBA, A.; WOOD-GUSH, D.G.M. The behavior of pigs in a semi-natural environment. Animal Production, v.48, p.419-425, 1989.

TERLOUW, E.M.C.; LAWRENCE, A.B.; ILLIUS, A.W. Relationship between agonistic behavior and propensity to develop excessive drinking and chain manipulation in pigs. Physiology \& Behaviour, v.50, p.493-498, 1991.

THODBERG, K.; JENSEN, K.H.; HERSKIN, M.S.; JORGENSEN, E. Influence of environmental stimuli on nest building and farrowing behaviour in domestic sows. Applied Animal Behaviour Science, v.63, p.131-144, 1999.

Received on April 8, 2004 and accepted on November 22, 2004 